\title{
Corrigendum: [Novel functional roles for PERIANTHIA and SEUSS during floral organ identity specification, floral meristem termination and gynoecial development]
}

\author{
Robert G. Franks* \\ Department of Plant and Microbial Biology, North Carolina State University, Raleigh, NC, USA \\ *Correspondence: rgfranks@ncsu.edu \\ Edited and reviewed by: \\ Stefan De Folter, CINVESTAV-IPN, Mexico
}

Keywords: corrigendum, hoyers, chloral hydrate, PERIANTHIA, SEUSS

\section{A commentary on}

Novel functional roles for PERIANTHIA and SEUSS during floral organ identity specification, floral meristem termination and gynoecial development

by Wynn, A. N., Seaman, A. A., Jones, A. L., and Franks, R. G. (2014) Front. Plant Sci. 5:130. doi: 10.3389/fpls.2014.00130

In "Materials and Methods" under the heading "Tissue Fixing and Clearing" we incorrectly described the composition of our Hoyer's solution. “... Hoyer's solution
(70\% ethanol, 5\% gum arabic, $4 \%$ glycerol)" should read “... Hoyer's solution (70\% chloral hydrate, 5\% gum arabic, $4 \%$ glycerol)."

Conflict of Interest Statement: The author declares that the research was conducted in the absence of any commercial or financial relationships that could be construed as a potential conflict of interest.

Received: 13 August 2014; accepted: 13 August 2014; published online: 29 August 2014.

Citation: Franks RG (2014) Corrigendum: [Novel functional roles for PERIANTHIA and SEUSS during floral organ identity specification, floral meristem termination and gynoecial development]. Front. Plant Sci. 5:434. doi: 10.3389/fpls.2014.00434

This article was submitted to Plant Evolution and Development, a section of the journal Frontiers in Plant Science.

Copyright (c) 2014 Franks. This is an open-access article distributed under the terms of the Creative Commons Attribution License (CC BY). The use, distribution or reproduction in other forums is permitted, provided the original author(s) or licensor are credited and that the original publication in this journal is cited, in accordance with accepted academic practice. No use, distribution or reproduction is permitted which does not comply with these terms. 